\title{
VAEKEHU, THE LIFE OF A 19TH CENTURY MARQUESAN “QUEEN" IN TURBULENT TIMES
}

\author{
CAROL S. IVORY
}

Washington State University

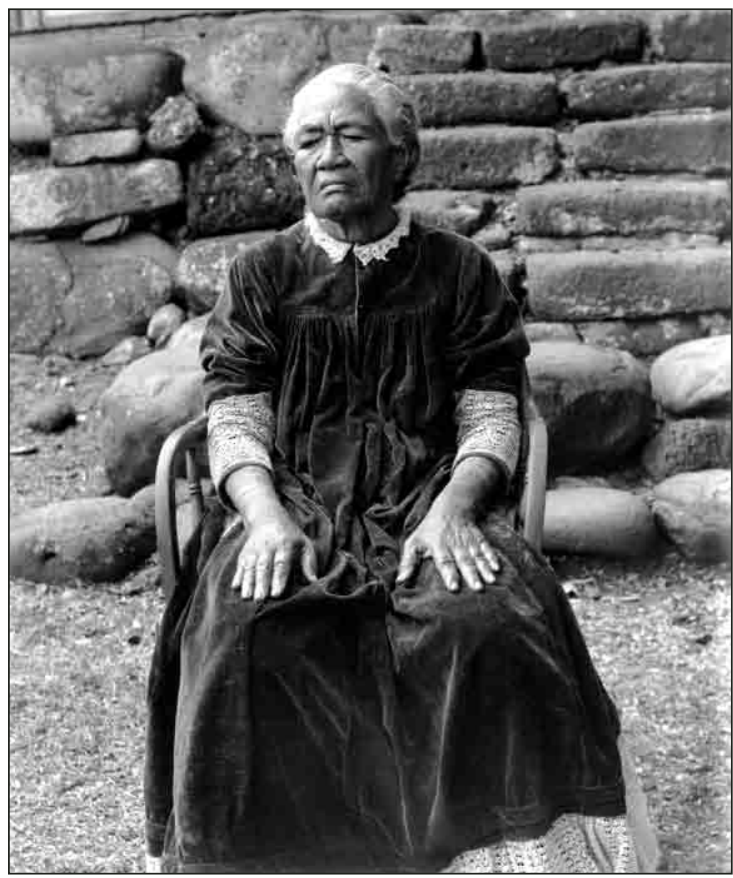

Figure 1. Vaekehu, Queen of the Marquesas. Neg. no. 121424. Photographer, Alfred G. Mayer, 1899. Courtesy Department Library Services, American Museum of Natural History.

There is perhaps no other Marquesan, woman or man, whose life more clearly mirrors the changes that occurred in the Marquesas Islands in the 19th century than Vaekehu (Fig. 1). Her story contains adventure and irony, violence and betrayal, dignity and courage. In its broad sweep and intimate detail, it brings to life and makes personal, abstract notions of power and status, gender relations, culture contact and historical change. 
Vaekehu was born on the island of Nuku Hiva (Fig. 2) around 1823, a high-ranking woman in a line of powerful and wealthy Marquesan women. She grew up in a period when many of the old ways were still vital and the structure of "traditional" Marquesan life remained intact. In her youth, she was extensively and exquisitely tattooed. She saw the arrival of missionaries, first Protestant in 1829, then Catholic a decade later, and the accession of the archipelago by the French in 1842. In the last half of the century, she watched her people die and her culture collapse around her. Strong-willed and courageous, Vaekehu became taciturn and withdrawn in her later years. She found peace in the religion of the Catholic missionaries, and became the stalwart supporter of the Catholic Church and the French government that, in her lifetime, subdued her people and transformed their way of life forever. By the time of her death in June 1901, at the age of 78, fewer than 4000 Marquesans remained of the estimated 100,000 a century earlier. ${ }^{1}$

Vaekehu's story begins with the complex genealogical interrelationships between her family and that of her husband, Temoana, which established their high-ranking status in Marquesan society. This status prompted the French to designate them "king" and "queen" of Nuku Hiva. ${ }^{2}$ The story continues with the chronicle of their often tumultuous years together as husband and wife. Finally, it follows the nearly 40 years after her husband's death, when Vaekehu lived as matriarch and titular monarch of an increasingly desolate Nuku Hiva. While numerous events in Vaekehu's later life are well-documented, the information about the earlier part is elusive, much like the personality that emerges in the anecdotes of the many missionaries, government officials and itinerant visitors to the islands who met and wrote about her.

\section{GENDER, RANK AND GENEALOGY: A CASE HISTORY}

One's genealogy is critical in establishing one's place in Polynesian societies, including the Marquesas Islands. The marriage of Vaekehu and Temoana was significant because it brought together bloodlines from many, if not all, of the major tribes and sub-tribes on Nuku Hiva, ensuring peace on the island. ${ }^{3}$ They were second cousins who shared a famous great-grandfather, Kiatonui, and great-grandmother, Tahiatai'oa. ${ }^{4}$

One of the lessons that research into the life of Vaekehu substantiates is that, in the Marquesas, women could, and often did, inherit and hold both property and titles, and wield great influence. ${ }^{5}$ Such was the case with Kiatonui's mother, Putahai' $i$, who though not first-born, was a powerful and wealthy woman in her own right. Edward Robarts, a beachcomber who lived in the Marquesas between 1797 and 1806, described Putahai'i's power: “... the favour of the old lady was worth the favour of the Whole family. Her word was a law. They 


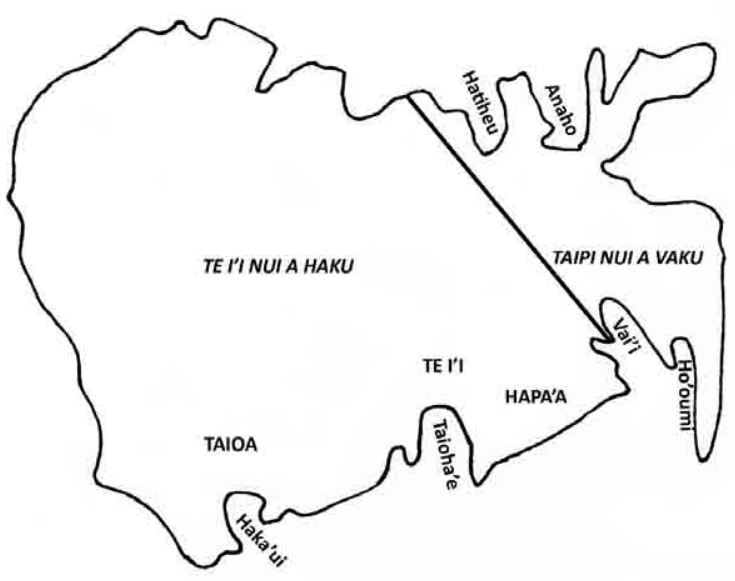

Figure 2. Map of Nuku Hiva. Valleys and bays; TRIBES.

even did not go to war without her consent. She was a woman of sound reason, her intelects [sic] Keen, and firm in her resolutions" (1974: 148).

Kiatonui, her son, was high chief of the powerful Te I'i tribe. As the result of his parents' marriage and his position as their first-born, Kiatonui brought together four of the six valleys of Taioha'e Bay (Pakiu, Ha'avao, Hoata and Meau). ${ }^{6}$ Once sustained European contact began in the early 19th century, this Bay became the political and commercial capital of the northern Marquesas. Kiatonui was the highest-ranking chief in Taioha'e when the Russian expedition under Capt. Adam von Krusenstern visited in 1804 and the Americans, under Captain David Porter, arrived in 1813.

Kiatonui married Tahiatai'oa, a highly ranked and powerful woman from a second important Nuku Hiva tribe, and Te I'i ally, the Tai'oa of Haka'ui, a valley to the west of Taioha'e. Their granddaughter, named Paetini, was born around 1798. She was the first-born daughter of a first-born daughter of a first-born son of a powerful mother and as a result, held chiefly rank in the Taioha'e, Haka'ui and Hapa'a valleys. She was a favourite of her greatgrandmother Putahai' $i$, had her own house that was tapu to all but her family, and her own personal guardian, Putahai 'i's youngest and favourite son. Paetini became famous when she met the American naval captain, David Porter, in 1813 , and the members of the Dumont d'Urville expedition in 1838. She was, according to Porter (1822 vol. II: 20), "held in great estimation, on account of her rank and beauty". 
Paetini's primary husband was the high chief of the Ho'oumi, one of several allied Taipi tribes that lived in the large bay to the east of Taioha 'e." As did the Te I' $i$, they included numerous sub-groups, and their influence extended over the entire eastern third of the island, including Hatiheu and Anaho valleys. They had a reputation as fierce warriors and were bitter enemies of the Te I' $i$. In the Marquesan custom, Paetini also had numerous vahana pekio 'secondary husbands', and perhaps a relationship with Porter, as well. ${ }^{8}$ Père Mathias Gracia (1843: 102-3) cited her as an example of a woman with title and power (here and elsewhere, translations from the French by the author):

She was the only heir of numerous districts and she had for principal spouse the chief or king of Oumis [Ho'oumi], distant by some miles, and who came to see her only every two or three months; but she had around her usually two or three other small chiefs, also called her spouses.... This queen was daughter, mother of kings and related to the majority of chiefs of the islands and the bays.

Paetini and her Ho'oumi husband had at least two daughters: Apekua, the elder, and Vaekehu, the younger. As a result of their genealogy, just described, these two daughters were highly ranked in the Taipi-Ho'oumi, Hapa'a, Tai'oa and Te I'i tribes. Each, in turn, married Temoana.

Temoana was also highly ranked and also traced his lineage back to Kiatonui and Tahiatai' 'oa. Charles Stewart, who visited Taioha 'e in 1829 when Temoana was about eight, wrote: "All the tribes, including the Taipis, partially at least acknowledge the boy [Temoana] — whose maternal grandmother is a chief woman of that tribe, still living at their principal valley - as the rightful prince of the whole [island] (1831: 303)."

\section{MARRIED LIFE WITH TEMOANA}

Marriages among high-ranking Marquesans were often arranged and served to establish or strengthen alliances between families or tribes. The marriage ceremony could take place when the husband and wife were young children, or even infants. Temoana's first marriage took place on 19 September 1833, when he was around 12 years old. It is recorded in detail in the journals of two missionaries from the American Board of Commissioners for Foreign Missions who witnessed the ceremony. The unnamed bride is described by the missionary, W.P. Alexander (1833), as being a "high chief among the Hapas [Hapa 'a]" who was " 2 or 3 years older" than Temoana (see also Armstrong 1833-34: 32).

Temoana left the Marquesas in 1834, shortly after this ceremony, and travelled on whaling ships to England and back. Robert Thomson (1978: 46, 
51), the missionary who accompanied him on his return in 1839, describes Temoana's "relapse into the savage", but makes no mention of a waiting wife or of a subsequent marriage (on this issue, see also Dening 1980: 151).

This young bride was most likely Apekua, the elder of the two sisters. By the time the French arrived in 1842 to take possession of the archipelago, Temoana had a wife named Tahia'oko, who is probably, but not definitely, Apekua. ${ }^{10}$ The number of children they had, either naturally or by adoption, is disputed, but we know that there was one son, Taniha (Stanislas) Moanatini, who survived and became Temoana's heir, and a blind daughter named Tikiahutini. ${ }^{11}$ According to Edmond de Ginoux (2001: 79), in 1849 when he visited Taioha'e, Tahia'oko had left Temoana for the third and final time and he had married the daughter of a chief of Ua Pou, who was "unwell and seemed to not have a long time to live".

By 1850, Vaekehu had become Temoana's wife. According to Le Cléach'h (n.d.: 1), like Temoana she had been married before - to a Hapa' a chief with whom she had a daughter (both apparently died early on). By all accounts, Vaekehu and Temoana had no children born of their union. According to her descendants, Vaekehu was required by custom to take her older sister's place as Temoana's wife and care for his children, Tikiahutini and Taniha, whom she adopted. Tikiahutini was still alive in 1852, but may have died not long after that; Taniha remained an important part of her life until his death in 1894.

Vaekehu was raised at a time when many Marquesan customs were still practiced, as evidenced by her extentive tattoos. From the late 1840s on, her tattoos were commented upon - and several times drawn - by nearly everyone who met her, and always in glowing terms. In the early $1850 \mathrm{~s}$, Jacques Arago (1854 vol. II: 13) wrote that Vaekehu was "truly queen because the designs of her body are magnificent... everyone admires them". Pierre Loti drew them in detail when he visited in 1872, noting (1976: 71) that Vaekehu consented "with perfect graciousness" to pose for him. She was still exhibiting them around 1883 when Aylic Marin met her ([E. Petit] 1891: 197). He reported: "When I had seen her, she deigned to permit me to admire her arms and her calves; the designs of her arms are especially remarkable; besides the name (which is always inscribed on the left arm), I saw on this royal skin a quantity of beautiful images, of small fish, of fruits, of leaves."

She had suffered great pain as a young girl when being tattooed; Marin reported that she nearly died as a result. Robert Louis Stevenson's mother, Margaret Stevenson, who met the queen in 1888 and quite liked her, wrote that, "The queen's hands are covered with the finest tattooing I have yet seen, all over the back, like exquisite lace mittens; but I noticed that only the first finger was done, the others being untouched. I asked her son the reason for 
this, and he shrugged his shoulders and said, 'It is too painful' "' (1903: 115). ${ }^{12}$ Albert Davin learned more about the queen's tattooing in 1886 . He quotes her (1886: 218-19) as saying, through her interpreter:

Oh I suffered cruelly. I cried much.... For several days my hands stayed large as breadfruits. It was in vain that I asked my mother to put an end to my suffering. All was useless. It was necessary that the tattooing of my hands and arms to my shoulders, of the feet and the knees, of the mouth and the ears, reveal my noble origin.

Davin went on to explain that the tattoos were by different artists from the island of Ua Pou (home of the best tattooers in the archipelago at that time) but done so well and so similarly that they appear the work of one.

Life with Temoana was difficult for Vaekehu as it had been for Tahia'oko, owing in part to his use and abuse of alcohol. In an 1850 incident, for example, Temoana declared war on the French when some soldiers killed two pigs. Actual hostilities were averted primarily through the efforts of Bishop Dordillon, the Catholic missionary, who noted (in Delmas 1929: 87-88): "His [Temoana's] wife was quite grieved [toute desolée], and attributed all to the drink." Arago, describing Temoana about the same time, said that he drank much wine, and would drink all the time if he could. After taking a short walk with the king, in which an inebriated Temoana managed to destroy two roofs and three dinghies, he quotes the king as defending himself, saying, "You see, I hit neither man nor woman" and intimated that the damage he did was good for his people, providing work for them (1854 vol. II: 8, 15).

The French continued to support Temoana and Vaekehu despite Temoana's erratic behaviour. However, in 1852, a serious incident took place in which Temoana and Vaekehu came to be at serious odds with the French, resulting in their arrest and deportation to Tahiti. Chaulet (1873: 109-16) recorded it in Vaekehu's own words, published later by Delmas (1929: 90-95), as recounted in the indented paragraphs below (my translation and summary from the French). Here we catch a glimpse of her strong personality, and of her courage and leadership role.

The situation involved an Italian by the name of Motto, who became an enemy of Temoana's when Temoana prevented Motto from bringing women to visiting ships to service the sailors. Shortly after this incident, the French Commandant at Taioha 'e, Bolle, demanded from Temoana some pigs that were being fattened in preparation for a feast to honour Temoana's deceased father. When the chiefs who were keeping the pigs in another valley came innocently to discuss the pig situation with Temoana, Motto told Bolle that they had actually come to plan a war. Bolle believed Motto, and relations became strained. 
Temoana, probably drunk according to Vaekehu, decided to go to Bolle to proclaim his innocence in any war scheme and at the same time to chastise Bolle for what he saw as unseemly approaches to the queen. Motto took advantage of this to accuse Temoana of various things, including nearly killing him. Other chiefs, enemies of Temoana, also came to accuse him. At Bolle's request, Temoana went to the government offices, only to be kept overnight under guard. The next morning Vaekehu, along with Bishop Dordillon, went to Bolle to entreat him to let Temoana go free. Vaekehu says she cried "hot tears" and finally, after consultation with Vincent, another French officer, Bolle let Temoana return home. Meanwhile the French prepared an assault on them.

Vaekehu and Temoana took their blind daughter, Tikiahutini, deep into the valley and returned alone to their house. Vaekehu improvised a French tricolore flag and again went with Dordillon, this time to entreat Bolle to call off his war with Temoana. Although he pitied her, Bolle refused her pleas. Vaekehu returned to her husband, her face covered, so as not to see the armed soldiers, her legs trembling, and several times nearly falling. She told her husband they must leave because a bombardment was about to start, Temoana responded that they were falsely accused and suggested they stay there to die.

Vaekehu, however, had other ideas. She pulled her husband out of the house, and then with the help of Temoana's grandfather forced him into the nearby Hoata valley, where they raised Vaekehu's flag. Motto convinced Bolle that this show of loyalty was merely a ruse, and the bombardment began, after which the French destroyed or stole all of their belongings. Motto, acting as Bolle's intermediary and interpreter, fanned the flames and convinced Bolle that Temoana was mocking and resisting him. Protesting his innocence, Temoana, accompanied by Dordillon went to Bolle's residence and was placed under house arrest.

According to Vaekehu, Bolle, thinking the people of Ho ' oumi were allies of Temoana, sent two ships to the neighbouring valley and, even though that all the inhabitants had fled, because they wanted no part in war, the ships bombarded and destroyed the valley. Bolle then exiled Temoana and Vaekehu, sending them to Tahiti on 8 October 1852. There Governor Page was convinced of their innocence and, after only ten days, sent them back to Taioha' ${ }^{6}$. As they had no residence, they had to stay with Bishop Dordillon. Governor Page came to Taioha'e in January 1853, reinstated the king and queen, reprimanded Bolle, and fired Motto.

On 29 June 1853,Vaekehu and Temoana, along with their families and many of their followers, 62 people in all, were baptised Catholic by Bishop Dordillon. Delmas stated that they had been thinking about converting since their return from Tahiti, so perhaps the move was in part political. ${ }^{13}$ The king and queen took the names Elisabeth (Eritapeta) and Charles (Karoro). A huge feast was held in which 80 large pigs were cooked. From this time 
on, they were faithful supporters of the Catholic Church and forged a deep and lasting relationship with Dordillon. Vaekehu, for example, adopted him (and numerous other missionaries) as her grandson, providing them with her personal protection (Delmas 1929: 97-98, R. Stevenson 1900: 78). ${ }^{14}$

Over the next nine years, Temoana and Vaekehu worked with Bishop Dordillon to convert their fellow Marquesans. Dordillon bought a boat, which he named "Elisabeth", to travel from valley to valley. Their methods were direct and often destructive. Captain W.T. McGrath, for example, in a letter (1912) told of an expedition in which the three came to the Hapa'a valley on board a French man-o'-war, and proceeded to defile the sacred paepae there by burning incense on them, spitting on the stone gods, and forcing women onto them. ${ }^{15}$ Temoana also fought a number of wars with neighbouring valleys in the name of religion - with the Tai'oa in 1859 and with the Taipi in 1862.

Temoana died 12 September 1863 of pleurisy. At the same time, Nuku Hiva and nearby Ua Pou were experiencing a horrendous epidemic of smallpox introduced when the French ship, Diamant, left 12 dying people in the care of the missionaries at Taioha 'e. Within seven months, over 1500 Marquesans perished. Vaekehu survived, taking refuge at the mission compound (Delmas 1929: 158-59, 168). Now began the final phase of her life, some 38 years as the "last queen" of Nuku Hiva.

\section{VAEKEHU, THE QUEEN, LIVES ON}

The last part of the 19th century was a very difficult time in Marquesan history, when people were dying and the culture was in collapse. ${ }^{16}$ Vaekehu, now a devout Catholic and financially supported by the French administration, took refuge in her new religion. By all accounts, she lived a mostly quiet life surrounded by children and grandchildren, and a retinue of women and men.

Various visitors mentioned that Vaekehu had both a daughter and a granddaughter named Elisabeth, and it appears that there were, in fact, at least two women with the name (in addition to Vaekehu herself). Davin (1886: 228) wrote that after having lost the daughter she had by Temoana (Tikiahutini?), Vaekehu adopted two children: Elisabeth, who had the dual role of interpreter and "lady of company", and Taniha/Stanislas. Loti (1976: 70), who visited Vaekehu in 1872, wrote of two women who served as "attendants" and interpreters for Vaekehu, one of whom was named Elisabeth, and Margaret Stevenson (1903: 109) noted that "an adopted daughter sat beside Vaekehu and acted as interpreter" in 1888 .

Stanislas was the high chief of Haka 'ui Valley and is spoken of frequently and in most positive terms by numerous visitors. Through the auspices of Bishop Dordillon, he attended school in Valparaiso, Chile, between 1856 and 1861. Stanislas helped bring about a peaceful accommodation with the 
French in the northern Marquesas in 1880, and then served as a civil servant and goodwill ambassador for the French until his death in 1894 (Marin 1891: 161, Rollin 1929: 286, R. Stevenson 1900: 69). He had two wives: first, Tahiakoetoa, a woman much his elder from Ua Pou; and then Sabine (Tahiautuani or Tahiautuoho), from Vaitahu on Tahuata (Chaulet 1873: 161, 179, Le Cleac'h n.d.: 1-2). Stanislas adopted Tahiakoetoa's daughter, Tonita Apekua, born in 1859, while he was a teenager and in Chile. She was living with Vaekehu in 1863 when the smallpox epidemic broke out and might be the Elisabeth who was later Vaekehu's interpreter (Chaulet 1873: 161, 205). Stanislas moved in with Sabine in the mid-1860s, by which time Vaekehu was a devout Catholic, and she now saw this as an adulterous relationship. This caused her great distress until the two married, many years later (Chaulet 1873: 179, Le Cleac'h n.d.: 2). Stanislas and Sabine had several children of whom two daughters survived: Elisabeth Vaekehu, born around 1865, who became high chiefess/queen of the island of Tahuata; and Marianne, born around 1872, who became chiefess of Haka'ui valley on Nuku Hiva. Willowdean Handy, who met Elisabeth Vaekehu in 1921, said she was adopted by Stanislas. Marin also specifically pointed out that one of the girls was Stanislas's "actual daughter", which was "a surprise in this place" where adoption was so common (Handy 1965: 42, Le Cleac'h n.d.: 2-3, Marin 1891: 256-57, Rollin 1929: 268). In 1873, a ceremony took place in which the then French administrator, Eyriaud des Vergnes, and Stanislas exchanged names and, at that time, Stanislas adopted an infant boy named Pakauoteia, who was known later as Rario (Delmas 1929: 267). Their descendants abound on several Marquesan islands today.

A visit to Vaekehu remained the highlight for many of the travellers who came through Taioha'e from this time until her death. Notable among her many visitors were Pierre Loti (1872), Robert Louis Stevenson (1888), F.W. Christian (1894) and Karl von den Steinen (1897). Those who visited the queen in the last decades of her life speak of her piety, her quiet dignity, her devotion to the Catholic Church, especially to the nuns with whom she spent much of her day, and her loyalty to the French. Many questioned how much she understood of her new faith, but none her devotion to or practice of it. Eyriaud des Vergnes noted, regarding her Catholicism, "We don't pretend that she has yet an exact idea of the importance of her acts, but she has the conviction at least to do well" (1877: 18; see also Caillot 1910: 380).

Vaekehu showed this firm commitment when she took a strong position regarding the practices and behaviour that would be acceptable at two festivals held at Taioha'e in 1869 (Delmas 1929: 215-17). The first of these was a traditional funerary feast ( $\mathrm{mau}$ ), given by a man named Pehipo. Delegations twice went to the queen to invite her to come. She refused, saying that she 
could not come, as this would be a pagan feast and she was a Christian and did not want to scandalise her subjects. The festival took place without the queen, but with the support of the French administrator, Eyriaud des Vergnes. It was, apparently, much in the old style, a veritable "abomination".

The second fête was planned for 15 August 1869, a feast day, and was to take place in a great house built in front of the queen's home. She shamed several people when she refused them lodging with her, fearing their lewd behaviour. She finally agreed to attend when promises were made that all would be proper, and this apparently was the case, at least until she and the nuns and clergy who accompanied her had left. Thereafter apparently the festival changed its tone. Though we do not know specifically what happened, the account speaks about "passions reawakened" and the lasting consequences of the débauche.

Vaekehu displayed her wealth and position, and the lingering hold of the old ways when she held her own feast to honour her dead husband Temoana, on 3 September 1872, nine years after his death. Such a feast would have been necessary in earlier times, and now she combined it with her new religion. Two hundred people from Nuku Hiva and Ua Pou attended a solemn mass, then moved in procession to Temoana's grave and, finally, shared a great feast (Delmas 1929: 264-65).

According to Eyriaud des Vergnes, her life was simple and all her needs met through an annual pension of 600 francs from the French government and from gifts given to her by Marquesans and by foreign visitors. She retained control of the valley of Haka 'ui and Collet Bay adjacent to Taioha'e, which, Marin says, she used as a vast park for her sheep and pigs. Davin tells of her love for cats and white chickens, both of which roamed freely in large numbers through her house (Davin 1886: 221, Eyriaud des Vergnes 1877: 18, Marin 1891: 189).

Vaekehu had two houses, near to each other, one European in style, always described as clean and neat, and one close by the sea built in Marquesan style on her mother, Paetini's, paepae 'stone platform' named Pikivehine. Her only "vice" seems to have been her fondness for her pipe, and as Mrs Stevenson recounts (1903: 109; see also Loti 1976: 70), an occasional adventure in rolling a cigarette. One of the most striking of her furnishings was a gold-framed lithograph of the Empress Eugénie, upon which was placed a handwritten card changing the identification to "Madame, Marechal de MacMahon". This naïve way of staying politically correct through changing French governments gave much amusement to her visitors (Blin 1881: 242, Davin: 1886: 217) ${ }^{17}$ For all of her retiring ways, Vaekehu became a respected, influential and judicious political leader, usually supporting the French government of the day. As late as the 1870 s she presided at meetings of the 
chiefs, where, Eyriaud des Vergnes reported (1877: 19), if they saw "her in accord with the [French] resident, one can be sure that the measure will be adopted unanimously, without any contrary manifestation; if necessary, Vaekehu addresses to all the chiefs some words which put to an end all hesitation on their part".

Despite this power, or perhaps because foreign visitors did not discern it, she was not considered to be particularly intelligent by many who described a vapid, lethargic scene surrounding the queen and her court. Loti (1976: 69, 71), for example, wrote:

Seated the whole day in a half-doze, they remain motionless and silent as idols. This is the court of Nuku Hiva, Queen Vaekehu and her retainers.... The thoughts that contort the strange face of the Queen remain a mystery to all, and the secret of her eternal reveries is impenetrable. Is it sadness or stupor? Is she dreaming about something or nothing at all? Does she mourn for her independence, and the savagery which is disappearing, and her people who are degenerating and becoming estranged from her?

Always such criticism is tempered with respect for her dignity. Caillot, who met her in 1900 not long before her death, said that she was "less intelligent than Queen Pomare [of Tahiti], but on the other hand, she was better than her; she had above all more dignity" (1910: 379). R.L. Stevenson and his family were quite taken with the queen in 1888 , and wrote warmly of her, and at length (1900: 71):

Vaekehu is very deaf; 'merci' is her only word of French; and I do not know that she seemed clever....[She] sat among us, eating or smoking her cigarette, quite cut off from all society, or only now and then included through the intermediary of her son. It was a position that might have been ridiculous, and she made it ornamental; making believe to hear and to be entertained; her face, whenever she met our eyes, lighting with the smile of good society; her contributions to the talk, when she made any, and that was seldom, always complimentary and pleasing. No attention was paid to the child [her great granddaughter], for instance, but what she remarked and thanked us for. Her parting with each, when she came to leave, was gracious and pretty, as had been every step of her behaviour. When Mrs. Stevenson held out her hand to say good-bye, Vaekehu took it, held it, and a moment smiled upon her; dropped it, and then, as upon a kindly afterthought, and with a sort of warmth of condescension, held out both hands and kissed my wife upon both cheeks.... when I kissed the little girl good-bye at the pier steps, Vaekehu gave a cry of gratification - reached down her hand into the boat, took mine, and pressed it with that flattering softness which seems the coquetry of the old lady in every quarter of the earth. 
Vaekehu's concern for her grandchildren and their legacy in the land embroiled her in something of a legal battle near the end of her life. Land rights were changing, and Vaekehu feared that the valley of Haka'ui, which her family controlled, might be sold. Before he died in 1894, Vaekehu had taken the dramatic step of adopting Stanislas under French law and legally deeding him the land so that the title could not be contested. In 1897, the inhabitants of Haka'ui, fearing that Marianne, now in possession of the valley, might try to profit by selling it to a European and expelling them, asked the queen to take back legal title. Vaekehu, accompanied by all of the people of Haka'ui and by her grandchildren, appeared one day in front of the Residence of the then administrator, one M. Thuret. There, in front of all, Marianne promised the inhabitants and their descendants that she would not sell the valley, and that they would be guaranteed ownership of the land they occupied. Satisfied with this solemn promise, Vaekehu withdrew her claim to the land. Sadly, in 1925 after Marianne died, her heirs sold the land and most of the inhabitants, dispossessed and ruined, were forced to move from the valley (Rollin 1929: 268-87, Handy 1965: 181).

It was sometimes hard for visitors to forget that the Marquesans had been (and in some instances in the late 19th century, still were) cannibals. This label was attached to the queen, at times in general terms, as when Loti (1976: 72) called her, "formerly a pagan and something of a cannibal". Even Robert Louis Stevenson (1900: 72) described her as "a queen of cannibals". By the $1890 \mathrm{~s}$, it had become a more specific charge. Hall and Osborne, who met her in the late 1890s wrote: "The common report about her, which I believe is true, is that years ago she got tired of her husband, the prince consort, and had him killed and ate him" (1901: 103). Some were more sceptical, though, such as Pallander, (1901: 257-58) who cautioned, “... if they should tell you the yarn about her having helped eat her first husband, you had best treat it as pure fable." Old stories die hard, though, for on the back of the photograph from the American Museum of Natural History used in this article (Fig. 1) was a handwritten note (probably copied from a note by the photographer, Alfred Mayer): "Vaekehu, queen of the Marquesas. She ate her first husband."

Vaekehu died in June 1901. She had been preparing for this event for a long time. Loti thought she was dying when he saw her, ill and having received the last sacrament, in 1872 (1976: 71-72). When Robert Louis Stevenson arrived in 1888 , her soul was at rest, he said, because, after ten years, the priests had finally allowed her to have her coffin (1900: $31-32) .{ }^{18}$ Caillot described her simple funeral in a footnote (1910: 380):

A long line of children preceded her body, followed by the brigadier of the gendarmerie, the head of the post office, representing the French government, 
the few foreigners established at Nuku-Hiva, and the natives of all the valleys of the islands, these latter crying and saying prayers. Rev. Chaulet led the religious ceremony.

She was laid to rest next to her husband in a small mausoleum perched on a little hill not far from the Catholic mission and her European-style home. She lies there today, her much-weathered mausoleum still overlooking her old paepae and Taioha'e bay.

$$
* * *
$$

Vaekehu's life was a testament to and a reflection of the fortitude and resilience of the Marquesan people. When she was born around 1823, Marquesans were still living much as they had for generations before them. Her status was determined by her genealogy, and it made her a very powerful and influential person, regardless of her gender. While still young, she was tattooed over major portions of her body. The designs remained visible her entire life and marked, as she said, "her noble origins". Given her high position and standing in numerous tribes that held power throughout the island, it is not surprising that, in the Marquesan way, her marriage was a highly political, if not always a happy one. Her union with Temoana, like that of her sister, was necessary to unite the island and ensure peace. In Marquesan fashion, also, she solidified this peace by adopting children and grandchildren from important families and from different valleys.

After Europeans arrived, particularly the French, she proved herself level headed and courageous, entering into negotiations to avoid war and mitigating her husband's often hot-headed and impetuous actions. She was the one in 1853 who made a French tricolore flag to attempt a truce, moved her family to safety, and maintained her dignity despite bombardment and imprisonment. In the end, she was loyal and stood by Temoana in changing, and often difficult, circumstances.

Her commitments to Catholicism and to the French were perhaps necessary if she were to remain influential and comfortable, particularly after Temoana's death in 1863. As a widow in a country where both the population and culture were dying convulsive deaths, it should not be surprising that Vaekehu should seek peace and some solace with the missionary nuns living near her. She set an example for her people to follow, living a quiet, if at times seemingly desolate, life. She graciously played the role of queen for the rest of her life, receiving visitors, using her influence to foster agreement among the island's chiefs and with the French administrators, trying to maintain peace and discourage behaviours that, no longer rooted in a meaningful cultural framework, only served to further demoralise many Marquesan people. 
When she died at the very beginning of the 20th century, the population was nearly at its lowest level and the archipelago a mostly forgotten outpost of the French empire. Both Marquesan people and culture, including many of the arts, were being lost. Their decline and eventual death, like Vaekehu's, seemed inevitable to many. Happily, this was not the outcome. The resiliency and spirit that Vaekehu personified has been reawakened in the Marquesas. The population is now well over 10,000 in the Marquesas (with a greater number of Marquesans living in Tahiti), and Marquesan culture is undergoing a veritable renaissance. It is fitting that Vaekehu and Temoana have been remembered and revered along the way.

In 1989, the Second Festival of Marquesan Art was held at Taioha'e. The festival grounds were built adjacent to where Vaekehu's paepae, Pikivehine, stands and the dates, 28-30 June, jointly commemorated the contemporary Autonomy Day holiday, as well as the date of Vaekehu and Temoana's baptism, 29 June 1853. Many large stone sculptures were carved and placed around the grounds for the Festival. One of these, carved by Severin Kahe'e Taupotini, is a replica of the Marquesan house that originally stood on her paepae and depicts the royal family. On one end of the house, Temoana looks out to the sea, and on the other, facing her hilltop grave, an image of Vaekehu fills the central spot. She has pride of place here and is flanked by Temoana and by smaller figures representing her descendants. Facing the land and the people, she remains a revered ancestor and role model, part of the past but still very present in the life of the people - enshrined in a most fitting and most moving monument to her memory.

\section{ACKNOWLEDGEMENTS}

I am indebted to Dr. Robert Suggs for his careful reading of and invaluable comments on an early draft; also to Bishop Hervé-Marie Le Cléac'h, Felicité Kimitete and her niece, Hélène Fougerousse, Debora and Lucien Kimitete, Caroline Teho Pahuatini, Rose Corser, Michel Bailleul, Heidy Baumgartner LeSage, Marc Ottino-Garanger and Daniel Blau for generously sharing their knowledge or assisting in my quest to find answers. Any errors are mine. The American Council of Learned Societies, the American Philosophical Society and Washington State University provided much appreciated financial support at different times during which I conducted research on Vaekehu, her life and her family.

\section{NOTES}

1. Archaeologist Robert C. Suggs (pers. comm., 1997) estimates this number based on reports by Capt. David Porter in 1813 (Porter 1822). 
2. It is important to note that unlike Pomare in the Society Islands or Kamehameha in Hawai' $i$, the Marquesas Islands were not unified under a single monarch, and no dynasty was founded. Temoana and Vaekehu were dubbed king and queen of the island of Nuku Hiva, but in reality in the Marquesas power remained a negotiated entity between high chiefs of the different valleys/tribes on the different islands. While Vaekehu was highly esteemed, as this narrative demonstrates, she had none of the authority or status of a European monarch.

3. There were two major tribal alliances on Nuku Hiva, one led by the Te I' $i$ and the other by the Taipi tribes. All Nuku Hiva tribes are descended from them. They trace themselves back to two brothers, Taipi nui a vaku and Te I'i nui a haku (Suggs pers. comm., 1997). Nuku Hiva is one of six inhabited islands in the Marquesan archipelago.

4. The genealogical material is drawn from Robarts (1974: 328), Thomas (1990: Fig. 4), Crook (1800) and Le Cléac'h (n.d.). There are numerous spellings for these Marquesan personal names, as well as for island and site names, in the literature. Except in direct quotes, the ones in this article agree, for the most part, with current common usage.

5. Père Mathias Gracia, an astute observer in the Marquesas between 1839 and 1842 , wrote that if there was no male heir, the only or oldest female inherited the authority and land of the chief, and she alone retained the title and authority (1843: 102). Two earlier visitors to Nuku Hiva, W.P. Crook (1800) and E. Robarts (1974) also mentioned several instances of women owning their own property or holding chiefly titles.

6. See Dening (1980: 78-83) for this paragraph and the following two.

7. These are the "Typee" of Herman Melville's book (1972) by the same name first published in 1846.

8. In the Marquesas, women (not men) had multiple spouses: a primary husband who was the recognised father of any children, as well as one or more secondary husbands, called vahana pekio. Paetini had 32 vahana pekio according to Max Radiguet (1929: 165).

9. Note that, again, a woman is cited and it is implied that it is through her that Temoana receives his status.

10. The family today insists that Temoana had only two wives, Apekua and Vaekehu, and do not recognise the name Tahia'oko. Marquesans did and still do have numerous names, add names for a variety of reasons and use different names in different situations, so it is entirely possible that Apekua used a different name after Temoana's return. Tahia'oko's own turbulent relationship with Temoana is described at length by Collet (1844) and Radiguet (1929), and is a story all its own.

11. Reports of the children (and grandchildren) of Temoana's marriages are contradictory and confusing. Sorting out and tracking down all of the names is daunting owing to numerous adoptions, the reoccurrence and overlapping use of names (Marquesan, French and French names translated to Marquesan), and conflicting birth and death dates, and is beyond the scope of this article. The information about Taniha and Tikiahutini is from O'Reilly (1979: 551). 
12. Karl von den Steinen illustrated his account with an 1849 drawing of a hand by Charles Noury and an 1846 sketch of a leg by naval Lt. Olivier, identified as Vaekehu's hand and leg (1925: 130, 106, 199). The drawing of the hand shows two fingers without tattoo marks. Steinen visited the Marquesas in 1897 and met Vaekehu then.

13. Steinen (1925: 39) attributed the conversion to the "obligation" Dordillon had placed on Temoana by helping to free him during this incident. I am grateful to Robert Suggs for his translation of this section of Steinen.

14. Adoption was (and is) a most frequent practice among Marquesans and children were (and are) often spoken for long before being born. Adoptions were desirable for many reasons, including, as has been documented in Vaekehu's life, political ones.

15. Delmas (1929: 113-16) also tells of Temoana breaking tapu as a way to undermine Marquesan religious practices. It should be noted that Delmas, who arrived in the Marquesas in 1886, depended in great part on the records made by Pere Chaulet (1873), as also did Rollin.

16. Dening (1980) sensitively describes this period and its horrors in Chapter 7: "Violent Death".

17. Marshal MacMahon served as Chief of State of France from 1873 to 1875 and as the first president of the Third Republic from 1875 to 1879 (http://en.wikipedia. org/wiki/Patrice_de_Mac-Mahon, Duke_of_Magenta, 12 April 2014).

18. It was common practice in the Marquesas to have one's coffin made before one died, and kept near in the last days (see Dening 1980: 181).

\section{ABSTRACT}

Born on Nuku Hiva around 1823, Vaekehu was a high-ranking woman in a line of powerful and wealthy Marquesan women. She grew up in a period when the "old ways" were still vital and the structure of "traditional" Marquesan life intact. She married Temoana, the island's highest-ranking chief; their high status led the French to dub them "king" and "queen" of Nuku Hiva. She lived until 1901, and her long life, which was recorded by numerous writers and artists, mirrored the dramatic changes that occurred in the archipelago in the 19th century because of depopulation, missionisation and colonisation.

Keywords: Marquesas, Vaekehu, colonial history, French Polynesia

Author contact address: Dr Carol Ivory, Professor Emerita, Washington State University, Pullman, Washington. Email: ivorycs@wsu, edu 